\title{
IDENTIFYING DETERMINANTS OF DEMAND FOR CONSTRUCTION USING AN ECONOMETRIC APPROACH
}

\author{
Heng JIANG a, Chunlu LIU ${ }^{\text {a,* }}$ \\ a School of Architecture and Built Environment, Deakin University, 1 Ghrenghap Street Geelong, Geelong, \\ Victoria 3220, Australia
}

Received 1 April 2013; accepted 3 October 2014

\begin{abstract}
Economic variation and its effects on construction demand have received a great deal of attention in construction economics studies. An understanding of future trends in demand for construction could influence investment strategies for a variety of parties, including construction developers, suppliers, property investors and financial institutions. This paper derives the determinants of demand for construction in Australia using an econometric approach to identify and evaluate economic indicators that affect construction demand. The forecasting contribution of different determinants of economic indicators and their categories to the demand for construction are further estimated. The results of this empirical study suggest that changes in consumer's expectation, income and production, and demography and labour force are closely correlated with the movement of construction demand; and 14 economic indicators are identified as the determinants for construction demand. It was found that the changes in construction price, national income, size of population, unemployment rate, value or export, household expenditure and interest rates play key roles in explaining future variations in the demand for construction in Australia. Some "popular" macroeconomic indicators, such as GDP, established house price and bank loans produced inconclusive results.
\end{abstract}

KEYWORDS: Construction demand; Determinants; Economic indicators; Vector error correction model

\section{INTRODUCTION}

The important role of the construction market in an economy is well recognized. Changes in construction industry activities will directly and indirectly influence other industries and ultimately affect the economy at all levels of life. Song and Liu (2006) found that the construction sector has a very strong link with other economic sectors such as manufacturing, utilities, commerce, transportation, finance and business services. The construction industry can be the main engine for economic growth (Ofori 1990). However, the construction market is greatly affected by the performance of the economy because the output of construction is a response to the demand for buildings which is a derived demand for other sectors. Akintoye and Skitmore (1994) used five factors, namely economic conditions, construction prices, real interest rates, unemployment levels and profitability, to model demand for three types of construction markets in the UK. Fan et al. (2010)

\footnotetext{
Corresponding author. E-mail: chunlu@deakin.edu.au
}

indicated that a change in interest rates can affect the lending costs for clients, contractors, developers and company profits. Relationships between these economic indicators and construction demand have been tested by previous researchers in order to construct a causal model which can then be utilised to forecast future change in construction demand.

Future demand for construction is one of the most important factors for clients in deciding on investment in construction. Construction contractors, who are aware of changes in future demand for their services can use this knowledge to help formulate appropriate pricing strategies and take appropriate action (Akintoye, Skitmore 1994). With regard to tenders, those who have knowledge of future demand can price their tenders more realistically and strategically, thereby increasing their chances of success (Hua 2000). For construction developers, the levels of demand indicate the possibility of a timely and profitable disposal of new developments (Hua 1998). Conversely, for construction firms, a knowledge of change in de- 
mand can help them to operate more efficiently through better planning and control of their activities (Hua 2000). Ultimately for the construction industry, future work-load planning cannot be appropriate or accurate without a good knowledge of future demand.

In order to forecast construction demand, construction economists employ various prediction techniques, including neural networks, multi-regression or advanced multivariate regression techniques, such as the vector autoregressive model, the vector error correction model etc. However, the selection of economic indicators in previous studies has mainly depended on human judgement. Studies in forecasting construction demand have shown that forecasts of demand for construction are inevitably inaccurate, mainly as a result of the lack of empirical studies on the determinants of construction demand (Fan et al. 2010).

The objectives of this paper are to demonstrate the use of an innovative selection approach to identify the determinants of demand in the Australian construction market, based on long-run and causal relationship estimates using construction demand and economic indicators; to evaluate the forecast contribution of each determinant of construction demand and; to compare and contrast the identified construction demand determinants and nondeterminants in this study with the economic indicators affecting construction demand found in previous research.

\section{UNDERPINNING LITERATURE ON CONSTRUCTION DEMAND}

Research into construction demand varies, but can be broadly categorised into four perspectives. The first of these is the analysis of the relationships between construction demand and economic indicators. Tang et al. (1990) and Akintoye and Skitmore (1994) both constructed three linear multi-regression models to estimate the relationships between the indicators and different types of construction demand in Thailand and the UK respectively. The authors stated that the selected economic indicators should be different when estimating residential construction, non-residential construction and 'other' construction demands. Hua (1998) discussed the relationship between residential construction demand and economic indicators through regression and artificial neural network techniques. Lopes et al. (2011) used a Granger causality test to analyse the relationships between the gross domestic product and construction demand in Cape
Verde. Myers (2008) concluded that demand for construction is affected by the construction price, price of other goods or services related to construction, income, government policy, consumer's expectation and other influencing factors.

The second perspective is demand forecasting. The forecasting methods for construction demand in the literature can be summarised into five types: using classical multi-regression, Box-Jenkins or benchmarking, artificial neural network techniques, two or three-stage least-squares regression and vector error correct (VEC) models. Classical multi-regression models were widely used to forecast the trends of construction demand in Thailand, UK and Singapore by Tang et al. (1990), Akintoye and Skitmore (1994) and Hua (1998) respectively. Hua (1998) compared the prediction accuracy of three forecasting models by using Singapore data. Hua found that the Box-Jenkins technique is suitable for making short-term forecasts; that the multi-regression technique always has a problem in modelling as the selection of indicators is affected by human judgement; and that the artificial neural network technique has poor explanatory capabilities. However, Fan et al. (2010) reported that the benchmarking model has less prediction errors than the multi-regression model when forecasting construction demand in Hong Kong during 1984 and 2005. Tse et al. (1999) discussed investment demand and traditional demand for new housing construction in Hong Kong based on the two-stage least-squares and three-stage least-squares regression models. Fan et al. (2010) indicated that the VEC model performs better than the multi-regression model for predicting demand for construction. This study focuses on selecting and measuring determinants for construction demand by estimating its relationships as determined by perspective one and highly related to perspective two. Selecting determinants is the prior stage for modelling and forecasting demand for construction.

Estimating house prices and construction prices or costs, based on the modelling of construction supply and demand, is the third research field. In a competitive market, price or cost is determined by the supply and demand of products or services across the industry. Ball et al. (1998) indicated that for each market sector, construction prices should be determined by the total demand. Construction prices differ by region, partly as a result of local resource and demand, as an increase in demand will lead to a rise in price. Gyourko and Saiz (2006) believed supply and demand in construction both determine the price of construction, as such 
they estimated a construction price using the construction demand and supply equilibrium model.

There is little research focusing on the fourth perspective, the effects of a specific event on construction demand. Hua (2005) estimated the dynamic effects of the 1997 Asian financial crisis on the demand for construction in Singapore using the auto-regressive-integrated moving average (ARIMA) model. Hua (2005) reported that the net effect of the Asian financial crisis on the demand from both the public and private sectors is different, with a positive response in the public sector and a negative response in the private sector. A study by Fan et al. (2010), also based on the ARIMA technique, discussed the effects of the SARS outbreak and the Asian financial crisis on the Hong Kong construction industry. The study concluded that while the total demand for construction was only slightly impacted by the SARS outbreak and financial crisis, but the financial crisis did influence the demand in the residential sector deeply.

Various variables have been used to represent the level of demand in the construction market, such as the number of building permits, the number of construction work approvals, the value of construction output or the value of investment in the construction industry. Gyourko and Saiz (2006) employed the number of housing permits as demand for housing construction. The authors claimed that recent construction activities can be measured by the average number of housing permits as these can be seen as the demand for new housing construction. In contrast, Tang et al. (1990) and Fan et al. (2010) adopted the value of construction work output to represent the demand for construction. These researchers believed that the output of construction work can be viewed as a reasonable proxy to the value of construction volume that the clients demand. The value of construction contract awarded or the value of construction work approved has been used to represent the demand for the construction industry because they are indicators of change in the level of construction demand (Hua 2005; Ofori 1990).

Although various techniques have been applied to estimate the relationships between economic indicators and construction demand, the long-term and short term dynamic relationships between relevant variables and movement of the construction market have rarely been discussed. More importantly, the predictive power of the economic indicators on the future construction demand is still unexplored. To address these research gaps, a series of advanced econometric techniques, including cointegration, causality and variance decomposition analyses, are employed in this research.

\section{KEY ECONOMIC INDICATORS AFFECTING CONSTRUCTION DEMAND}

Many attempts have been made to provide explanatory parameters for demand fluctuations in the construction industry. For instance, Akintoye and Skitmore (1994) used five factors; economic conditions, construction price, real interest rate, unemployment levels and profitability, to model demand for three types of construction markets in the UK. Five macro-economic indicators, such as GDP, unemployment rates, tender price index, population and interest rates were selected to explain the variation in demand for construction in Hong Kong ( $\mathrm{Ng}$ et al. 2011). Based on the theory of demand, Myers (2008) presented the demand for construction in the form of a general equation as follows:

$$
Q_{c}^{D}=f\left[P_{c}, P_{x}, I, E X P, \ldots\right),
$$

This is formally referred to as a demand function. The function states that $Q_{c}^{D}$ is the demanded value of the construction products or services $f$ is a function of all the things listed inside the bracket: $P_{c}$ the construction price, $P_{x}$ the prices of other goods related to construction, $I$ income, EXP consumer's expectations, and a host of other things. Based on the law of demand the construction price is the main determinant for construction demand. There are many nonprice factors, such as changes of economic conditions, the cost of financing (interest rates), technology developments, demographic factors, labour force, seasonal differences, location, and so on (Myers 2008). This publication summarized the key factors of construction demand into five generalized categories, namely: prices, income and production, demography and labour force, consumer's expectations, and other factors. Furthermore, a number of previous studies indicated that construction supply is influenced by construction prices, productivity, land supply, competitive intensity and seasons (Akintoye, Skitmore 1991; Gyourko, Saiz 2006). Thus the economic indicators that can only affect construction supply, (e.g. land supply, construction productivity and competitive intensity) are excluded in the estimation of construction demand determinants.

Quarterly economic indicators used in this study are abstracted from the Australian Bureau of Statistics (ABS), and further classified into the five general categories as mentioned above, shown in Table 1. A justification on the choice of indicators is provided below. 


\section{Prices}

Construction prices are market driven, which are determined by the levels of demand and supply (Ball et al. 1998). At the same time, prices also affect the levels of demand according to the law of demand. When the construction market attains a high cost, a lower level of construction will be demanded than during periods of lower cost and vice versa. The changes in property prices and construction related price indexes are highly correlated with demand for construction (Ofori 1990; Tse et al. 1999). Demand curves are always plotted on the assumption that the prices of other commodities relate to the construction industry, particularly in the housing, import and export markets (Myers 2008).

\section{Income and production}

For most goods, an increase in income will lead to a rise in demand, particularly in the construction industry. Changes in national income or GDP can Granger cause variations in construction demand and activities (Akintoye, Skitmore 1994). Any variation in the national income will affect the level of demand for construction in both the private and public sectors. Changes in industrial and manufacturing production or output will affect product availability and demand for construction, as strong links were found among the construction sector and other sectors (Song, Liu 2006).

\section{Demography and labour force}

Demographic change is another factor influencing the need for various construction facilities and has been widely used for modelling and forecasting construction economic indicators such as demand and price. A change in the growth rate of population would lead to an expansion of developed land and hence influence the demand for construction. Variations in the labour market would affect construction supply and prices, which may indirectly affect demand for construction (Wong et al. 2007).

\section{Consumer's expectation}

Consumer views on future trends of expenditures, interest rates, unemployment rates and retail trading values may affect demand for construction, because these factors are commonly viewed as indicators of consumer's expectations to the future construction market. A higher expenditure and retail trading value represents more confidence on future national economy from consumers. Also, a lower local unemployment rate would represent a better macroeconomic stabilization. A rise in unemployment may discourage investment in the construction market because employment is the main source of income for residents and an increase in the unemployment rate represents a lowering of the purchasing power of the population as well as a lower demand.

Table 1. A summary of economic indicators based on five general categories that can affect construction demand

\begin{tabular}{|c|c|}
\hline Categories & Economic indicators \\
\hline Prices & $\begin{array}{l}\text { Construction producer price index (CPPI) } \\
\text { Established house price index (EHPI) } \\
\text { New house price index (NHPI) } \\
\text { Import price index (IMPI) } \\
\text { Export price index (EXPI) }\end{array}$ \\
\hline Income \& production & $\begin{array}{l}\text { National income (NI) } \\
\text { Gross domestic product (GDP) } \\
\text { Average weekly earnings (AWE) } \\
\text { Construction company profit (CCP: before tax) } \\
\text { Industrial production index (IPI) } \\
\text { Total Manufacturing production index (TMPI) }\end{array}$ \\
\hline Demography and labour force & $\begin{array}{l}\text { Size of population (POP) } \\
\text { Employed person in the construction industry (EPCI) } \\
\text { Labour cost (LC) }\end{array}$ \\
\hline Consumer's expectation & $\begin{array}{l}\text { Household expenditure (HHE) } \\
\text { Government expenditure (GE) } \\
\text { Unemployment rate (UR) } \\
\text { Interest rate (IR) } \\
\text { Value of retail trade (RT) }\end{array}$ \\
\hline Other factors & $\begin{array}{l}\text { International investment position (IIP) } \\
\text { Value of import of goods and services (VOI) } \\
\text { Value of export of goods and services (VOE) } \\
\text { Bank loans (BL) } \\
\text { Value of housing finance commitments (VHFC) } \\
\text { Australian stock market index (SPI) }\end{array}$ \\
\hline
\end{tabular}




\section{Other factors}

Some other factors have been employed in estimating construction demand, such as bank lending, value of import and export, international investment and housing finance commitments (Hua 1998; Ofori 1990). International investment, value of import and export are generally considered as barometers of national economy. The international investment position measures the aggregate of the net flow, which indicates the change in the level of net foreign investment in Australia. Changes in bank lending represent variations in the level of money supply in the construction market, which can affect demand for construction directly. The housing construction market operates as a substitute for the stock market for the urban household, and a substitute relationship would be expected between construction demand and the stock market index. Beside of the economic indicators, other factors, government policy, seasonality, the financial crisis and other special events, also can affect demand for construction. However, this study focuses on exploring the key influencing economic indicators of construction demand only.

In Australia, the construction industry contains house construction, residential building construction, non-residential building construction and engineering construction sectors. In the research presented in this paper, the approved values of both residential and non-residential building construction works were used as the proxy value of demand for construction in Australia. They can be explained as the total monetary cost of the building construction work that clients can, and will be able to, purchase in a certain period. Due to the lack of engineering construction data in the study period, the demand for engineering construction was excluded in the research study. The quarterly data series of selected economic indicators and the demand for construction are abstracted from the ABS for the periods of September 1996 and December 2009. This study period can be seen as a period of unusually stable construction demand, with Australia being affected less by the latest economic recession than some other nations. The time series data used in this study are expressed as natural logarithm variables. In the collection of variables for estimation, the following important issues are taken into account: the economic plausibility of their leading character, the availability of the time series with as few interruptions as possible and the availability of the data with minimum delay (Jiang, Liu 2011).

\section{ECONOMETRIC METHODS BASED DETERMINANT IDENTIFICATION}

A well-executed econometric analysis approach is utilised to identify and evaluate the determinants of demand in the construction market. A schematic flow chart highlighting the identification of determinants and the evaluation procedure is shown in Figure 1. The key influencing factors of construction demand are identified by long-run and short-run causal relationship estimation; subsequently, the identified influencing factors are further evaluated by forecast contribution variance decomposition analysis. A prior condition for the cointegration test is that all the variables should be integrated at the same order or contain a deterministic trend and accordingly a unit root test is conducted for each variable using the PP unit root test (Luo et al. 2007).

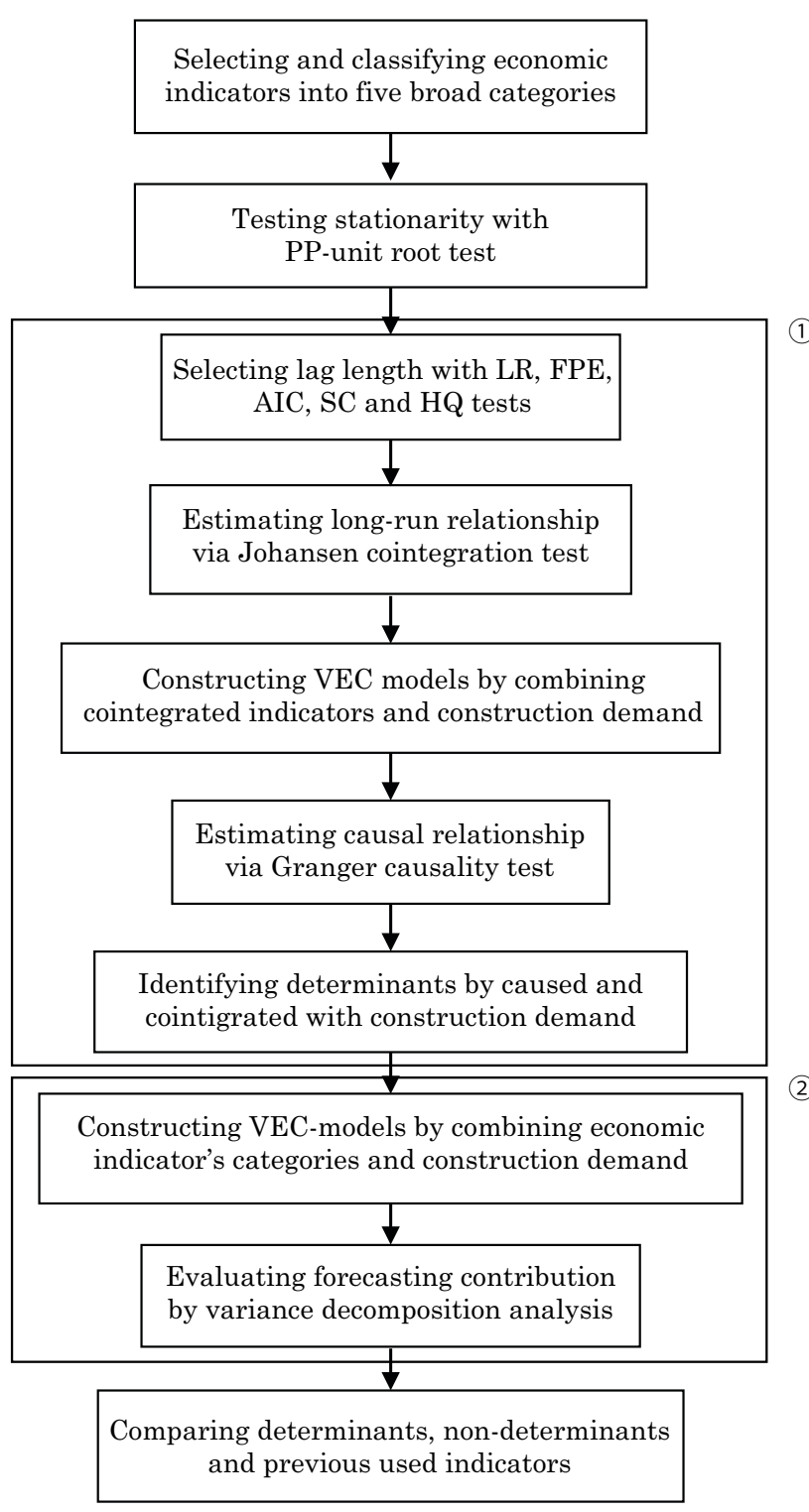

Fig. 1. Procedure of measurement of the determinants for construction demand 


\section{MODEL DEVELOPMENT FOR IDENTIFYING DETERMINANTS}

The vector error correction model is employed to test long-run and causal relationships in order to identify determinants in module one. Lag length of the VEC model is selected on the basis of the sequential modified LR test statistic, final prediction error (FPE), Akaike information criterion (AIC), Schwarz information criterion (SC) and HannanQuinn information criterion (HQ). The test results of lag length selection are then inputted into Johansen cointegration tests for constructing VEC models with different combinations between construction demand and each economic indicator.

Cointegration, an econometric property of time series variables, is generally used to estimate the long-run relationships between non-stationary variables. If the level of the time series data is not stationary but a linear combination of variables is stationary after first difference, then the series can be said to be co-integrated of order one or I(1). They will tend to come back to the trend in the long run, even though they deviate from each other in the short run. The Johansen cointegration test by a multivariate maximum likelihood approach was conducted to reveal the number or cointegration equations without using arbitrary normalisation rules. There are five models used in the Johansen cointegration test. Model one represents all series with zero mean. Model two represents deterministic data with an intercept but no trend in the CE. Model three suggests that data has a linear trend with an intercept but no trend in the CE. Model four has a linear trend with both an intercept and a trend in the CE, while model five suggests a quadratic data trend with an intercept and a trend in the cointegration equations (CE). This paper analyses three different specifications in the Johansen cointegration estimation, model 1 and 5 being excluded from the estimation due to issues of applicability to real life (Hui, Yue 2006).

The Granger causality test is a technique for determining whether one time series is useful in forecasting another. An unrestricted vector autoregression model (VAR) is usually assumed to implement the Granger causality test, but a VAR model for the Granger causality test will contain some misspecification when time variables are cointegrated. Therefore, this kind of test should be processed using a vector error correction model. Once all variables are proved to be stationary and co-integrated, a vector error correction model can be formulated. The VEC model can be defined by Eq. (2):

$$
\Delta Y_{t}=C+\Pi Y_{t-1}+\sum_{i=1}^{k-1} \Gamma_{i} \Delta Y_{t-i}+\varepsilon_{t}
$$

where: $Y_{t}$ is the independent $\mathrm{I}(1)$ variable being integrated to an $\mathrm{I}(0)$ vector; $\mathrm{C}$ is the intercept; $\Gamma$ is the matrix reflecting the short-run dynamic relationship among the elements of $Y_{t}$; and $\varepsilon_{t}$ is residual. $\Delta=(\mathrm{I}-L), L$ is the lag operator, where $\Pi$ is the matrix containing long-run equilibrium information. If the elements of $Y_{t}$ are I(1) variables and co-integrated with $\operatorname{rank}(\Pi)=r<p$, then the rank of $\Pi$ can be rewritten as $\Pi=\alpha \beta^{\prime}=\alpha e c m_{t-1}$ , ecm $m_{t-1}$ is the error correction term and $\beta^{\prime} Y_{t}$ is stationary. This implies that $r<p$ stationary linear combinations of $Y_{t}$ exist. $\beta$ is a vector of cointegration relationships and $\alpha$ is a loading matrix defining the adjustment speed of the variables in $Y$ to the long-run equilibria defined by the co-integrating relationships.

Specifically the VEC model for construction demand $\left(C D_{t}\right)$ can be written as:

$$
\begin{aligned}
& \Delta C D_{t}=C+\alpha\left(e c m_{t-1} Y_{\mathrm{t}-1}+\rho_{0}\right)+\sum_{i=1}^{k} \theta_{1, i} \Delta C D_{t-i}+ \\
& \sum_{i=1}^{k} \theta_{2, i} \Delta X_{1, t-i}+\ldots+\sum_{i=1}^{k} \theta_{j, i} \Delta X_{j+1, t-i}+\varepsilon_{t} \ldots,
\end{aligned}
$$

where: $\alpha$ is the adjustment coefficient; $\rho_{0}$ is the intercept of co-integrating equations. $\theta_{j, i}$ reflect the short-run aspects of the relationships between the independent variables and the target variable, $X_{j+1, t-i}$ are the variables of economic indicators.

\section{ECONOMETRIC TECHNIQUE FOR EVALUATING DETERMINANTS}

Once the determinants of construction demand have been identified, a variance decomposition technique is employed to explore the forecast error for each determinant and the category of economic indicators in module two. The variance decomposition technique splits the forecast error variance into components which can measure the contribution of every target variable in each of the future periods (Liu et al. 2009). The VEC model based on Eq. (2) can be written as:

$$
Y_{t}-Y_{t-1}=C+\Pi Y_{t-1}+\sum_{i=1}^{k-1} \Gamma_{i}\left(Y_{t-i}-Y_{t-i-1}\right)+\varepsilon_{t}
$$

The expression for $Y_{t}$ can be rewritten as:

$$
\begin{aligned}
& Y_{t}=C+\left(I+\Pi+\Gamma_{1}\right) Y_{t-1}+ \\
& \left(\Gamma_{2}-\Gamma_{1}\right) Y_{t-2}+\cdots+\Gamma_{\mathrm{k}-1} Y_{t-k+1}+\varepsilon_{t} .
\end{aligned}
$$


Write Eq. (4) as:

$$
\Phi(\mathrm{L}) Y_{t}=\varepsilon_{t},
$$

where: $\mathrm{L}$ is the lag operator. The variance decomposition is based on the concept of the infinite vector moving average expression of Eq. (6). Since $\Phi(\mathrm{L}) Y_{t}$ is stationary:

$Y_{t}=\Phi(\mathrm{L})^{-1} \varepsilon_{t}=A(\mathrm{~L}) \varepsilon_{t}=A_{0}+A_{1} \varepsilon_{t}+A_{2} \varepsilon_{t-1}+\cdots,(7)$

where: $A_{0}, A_{1}, A_{2}, \cdots$ are constructed as:

$$
\begin{aligned}
A_{0} & =\left(\begin{array}{c}
a_{1} \\
a_{2} \\
\vdots \\
a_{n}
\end{array}\right), A_{1}=\left(\begin{array}{cccc}
a_{1,1}^{(1)} & a_{1,2}^{(1)} & \cdots & a_{1, n}^{(1)} \\
a_{2,1}^{(1)} & a_{2,1}^{(1)} & \cdots & a_{2, n}^{(1)} \\
\vdots & \vdots & \cdots & \vdots \\
a_{n, 1}^{(1)} & a_{n, 2}^{(1)} & \cdots & a_{n, n}^{(1)}
\end{array}\right), \\
A_{2} & =\left(\begin{array}{cccc}
a_{1,1}^{(2)} & a_{1,2}^{(2)} & \cdots & a_{1, n}^{(2)} \\
a_{2,1}^{(2)} & a_{2,1}^{(2)} & \cdots & a_{2, n}^{(2)} \\
\vdots & \vdots & \cdots & \vdots \\
a_{n, 1}^{(2)} & a_{n, 2}^{(2)} & \cdots & a_{n, n}^{(2)}
\end{array}\right), \cdots
\end{aligned}
$$

Substitute $A_{0}, A_{1}, A_{2}, \cdots$ into Eq. (8):

$$
\begin{aligned}
& \left(\begin{array}{c}
X_{1, t} \\
X_{2, t} \\
\vdots \\
X_{n, t}
\end{array}\right)=\left(\begin{array}{c}
a_{1} \\
a_{2} \\
\vdots \\
a_{n}
\end{array}\right)+\left(\begin{array}{cccc}
a_{1,1}^{(1)} & a_{1,2}^{(1)} & \cdots & a_{1, n}^{(1)} \\
a_{2,1}^{(1)} & a_{2,1}^{(1)} & \cdots & a_{2, n}^{(1)} \\
\vdots & \vdots & \cdots & \vdots \\
a_{n, 1}^{(1)} & a_{n, 2}^{(1)} & \cdots & a_{n, n}^{(1)}
\end{array}\right)\left(\begin{array}{c}
\varepsilon_{1, t} \\
\varepsilon_{2, t} \\
\vdots \\
\varepsilon_{n, t}
\end{array}\right)+ \\
& \left(\begin{array}{cccc}
a_{1,1}^{(2)} & a_{1,2}^{(2)} & \cdots & a_{1, n}^{(2)} \\
a_{2,1}^{(2)} & a_{2,1}^{(2)} & \cdots & a_{2, n}^{(2)} \\
\vdots & \vdots & \cdots & \vdots \\
a_{n, 1}^{(2)} & a_{n, 2}^{(2)} & \cdots & a_{n, n}^{(2)}
\end{array}\right)\left(\begin{array}{c}
\varepsilon_{1, t-1} \\
\varepsilon_{2, t-1} \\
\vdots \\
\varepsilon_{n, t-1}
\end{array}\right)+\cdots
\end{aligned}
$$

Defining $X_{1, t}=C D_{t}$, the corresponding VEC model based on Eq. (8) for construction demand, can be written as:

$$
C D_{t}=a_{1}+\sum_{j=1}^{n}\left(a_{i, j}^{(1)} \varepsilon_{j, t}+a_{i, j}^{(2)} \varepsilon_{j, t-1}+\cdots\right) .
$$

Variance decomposition provides insight into the relationship between variables by measuring the contribution of all variables to the variance, namely the relative variance contribution (RVC). $\mathrm{RVC}$ of determinants to construction demand is expressed in Eq. (10):

$$
R V C_{j \rightarrow C D}(s)=\frac{\sum_{q=1}^{s}\left(a_{i j}^{(q)}\right)^{2} \operatorname{Var}\left(X_{j, t}\right)}{\operatorname{Var}\left(C D_{t}\right)},
$$

where: $s$ denotes the number of future periods; $X_{j, t}$ denote the variables of determinants. This equation forecasts the contribution of the variable $j$ to the variance of the demand for construction in the future period. Thus, the variance decomposition is the ratio of the contribution that ascertains how much the forecast error variance accounts for each variable, and it can distinguish the key factors which have more influence on other variables in the VAR system.

\section{EMPIRICAL RESULT}

\subsection{Causal relation of determinants of construction demand}

\begin{tabular}{|c|c|c|c|c|}
\hline \multirow[t]{2}{*}{ Indicators } & \multicolumn{2}{|l|}{ Level } & \multicolumn{2}{|c|}{ First difference } \\
\hline & PP t-Stat & $\mathrm{P}$-value & PP t-Stat & $\mathrm{P}$-value \\
\hline CPPI & -1.879 & 0.651 & -3.094 & $0.033^{*}$ \\
\hline EHPI & -1.476 & 0.825 & -3.204 & $0.026^{*}$ \\
\hline NHPI & -2.496 & 0.329 & -4.577 & $0.000 * *$ \\
\hline IMPI & -2.041 & 0.565 & -5.225 & $0.000 * *$ \\
\hline EXPI & -2.581 & 0.290 & -3.240 & $0.002^{* * *}$ \\
\hline NI & -2.468 & 0.342 & -2.578 & $0.011^{*}$ \\
\hline GDP & -0.275 & 0.921 & -11.152 & $0.000 * *$ \\
\hline AWE & -2.797 & 0.205 & -5.535 & $0.000^{* * *}$ \\
\hline $\mathrm{CCP}$ & -2.772 & 0.214 & -9.606 & $0.000 * *$ \\
\hline IPI & -1.873 & 0.654 & -5.637 & $0.000 * *$ \\
\hline TMPI & -1.302 & 0.877 & -5.817 & $0.000 * *$ \\
\hline POP & 3.004 & 1.000 & -3.823 & $0.005^{* *}$ \\
\hline EPCI & -0.211 & 0.930 & -7.508 & $0.000 * *$ \\
\hline $\mathrm{LC}$ & -3.109 & 0.115 & -7.100 & $0.000 * *$ \\
\hline HHE & -1.071 & 0.924 & -2.352 & $0.019^{*}$ \\
\hline GE & -0.326 & 0.914 & -12.421 & $0.000 * *$ \\
\hline UR & -0.398 & 0.985 & -3.878 & $0.000 * *$ \\
\hline IR & -2.217 & 0.470 & -4.302 & $0.000 * *$ \\
\hline $\mathrm{RT}$ & -1.699 & 0.738 & -5.415 & $0.000 * *$ \\
\hline IIP & -1.828 & 0.677 & -4.325 & $0.000 * *$ \\
\hline VOI & -1.872 & 0.655 & -3.898 & $0.000 * *$ \\
\hline VOE & -2.284 & 0.181 & -7.261 & $0.000^{* *}$ \\
\hline $\mathrm{BL}$ & -1.882 & 0.650 & -4.317 & $0.001 * *$ \\
\hline VHFC & -2.903 & 0.170 & -3.176 & $0.002^{* * *}$ \\
\hline SPI & -2.157 & 0.503 & -5.314 & $0.000 * *$ \\
\hline$C D$ & -0.119 & 0.942 & -7.022 & $0.000 * *$ \\
\hline
\end{tabular}

The identification of determinants begins with the stationary test for each series while the results are summarized in Table 2 . The null hypotheses of non-stationarity are performed at the $1 \%$ and $5 \%$

Table 2. Stationarity test for the economic indicators and construction demand

* denotes rejection of null hypothesis of unit root based on their P-value at the 0.05 significance level.

** denotes rejection of null hypothesis of unit root based on their $\mathrm{P}$-value at the 0.01 significance level. 
significance level. The PP test results indicate that the series of construction demand and all selected economic indicators are stationary after the first difference during September 1996 and December 2009. When the multiple individual time-series variables are found to be integrated of order one, an additional test is required to determine whether a long-run relationship exist between construction demand and each economic indicator.

Long-run relationships between construction demand and economic indicators are estimated via Johansen cointegration tests. The indicators which have a long-run relationship with construction demand are summarized in Table 3. There are 17 long-run relations found between construction demand and key economic indicators from 1996 to 2009 based on the results of trace and max-Eigen statistics tests. The test results suggest that the gross domestic product, the international investment position, the value of import of goods and services, the value of retail trade, the total manufacturing production index, the established house price index, the employed person in the construction industry and the Australian stock market index have no cointegration with construction demand in Australia. Despite the GDP being employed for modelling construction demand in some previous studies, the causality link between construction output or activities and the GDP is still inconclusive, for example in the study of $\mathrm{Ng}$ et al. (2011). Generally, the fixed capital consumption has a strong link with the construction industry. Because the fixed capital consumption was deducted from the GDP measurement, there was non-significant relationship between GDP and construction demand in the long-run. The economic indicators which have no long-run relationships with construction demand were excluded from further estimation.

Table 3. The economic indicators co-integrated with construction demand

\begin{tabular}{ll}
\hline Model specification & Indicators \\
\hline M2 & CPPI, EXPI, NI, LC, HHE, IR, \\
& VHFC \\
M3 & NHPI, AWE, IPI, POP, BL \\
M4 & IMPI, VOE, CCP, GE, UR \\
\hline
\end{tabular}

Since certain economic indicators and construction demand proved to be integrated and co-integrated, vector error correction models could be formulated based on Eq. (3). Each pairwise combination of construction demand and one of economic indicators was tested. Subsequently the causality relationships between construction demand and the selected economic indicators were examined using the VEC-Granger causality test, the results of which are summarized in Table 4 . The results suggest that a change of the import price index, construction company profit and the value of housing finance commitments cannot Granger cause a change in demand for construction. Generally, for construction companies, high profitability may encourage investment which can increase construction production and influence the level of construction supply. However, the profits of construction companies would not cause the change in demand for the construction market. The result of the Granger causality test confirms that construction company profit cannot Granger cause construction demand. No causal relationship was found between the value of housing finance commitments to the level of demand for construction, mainly because over $90 \%$ of the value of housing finance is invested in the established housing market not the new housing construction market in Australia (ABS 2011). The test results also suggest that national income, value of exports, household and government expenditure, the industrial production index, the construction producer price index, the new house price index, the import price indices, unemployment rates, popula-

Table 4. Causal relation estimation for the selected indicators and construction demand

\begin{tabular}{lll}
\hline Direction of causality & Chi-square & P-value \\
\hline $\mathrm{CPPI} \rightarrow \mathrm{CD}$ & 11.09 & 0.01 \\
$\mathrm{NHPI} \rightarrow \mathrm{CD}$ & 10.87 & 0.05 \\
$\mathrm{IMPI} \rightarrow \mathrm{CD}$ & 2.86 & $0.12^{*}$ \\
$\mathrm{EXPI} \rightarrow \mathrm{CD}$ & 23.62 & 0.00 \\
$\mathrm{NI} \rightarrow \mathrm{CD}$ & 10.94 & 0.00 \\
$\mathrm{AWE} \rightarrow \mathrm{CD}$ & 4.93 & 0.09 \\
$\mathrm{IPI} \rightarrow \mathrm{CD}$ & 10.26 & 0.02 \\
$\mathrm{CCP} \rightarrow \mathrm{CD}$ & 2.02 & $0.36^{*}$ \\
$\mathrm{POP} \rightarrow \mathrm{CD}$ & 17.05 & 0.00 \\
$\mathrm{LC} \rightarrow \mathrm{CD}$ & 13.25 & 0.00 \\
$\mathrm{HHE} \rightarrow \mathrm{CD}$ & 9.46 & 0.00 \\
$\mathrm{GE} \rightarrow \mathrm{CD}$ & 10.15 & 0.02 \\
$\mathrm{UR} \rightarrow \mathrm{CD}$ & 3.35 & 0.07 \\
$\mathrm{IR} \rightarrow \mathrm{CD}$ & 24.81 & 0.00 \\
$\mathrm{VOE} \rightarrow \mathrm{CD}$ & 6.90 & 0.03 \\
$\mathrm{BL} \rightarrow \mathrm{CD}$ & 14.75 & 0.00 \\
$\mathrm{VHFC} \rightarrow \mathrm{CD}$ & 9.01 & $0.17^{*}$ \\
\hline$*$
\end{tabular}

* denotes the acceptance of no Granger causality at the 0.1 significance level. 
tion, average weekly earnings, labour costs, bank loans and interest rates have causal relations with demand for the construction market. As such, 14 economic indicators have been identified as determinants of construction demand after long-run and causal relationship estimations.

\subsection{Predictive power of determinants of construction demand}

To obtain further insights into the influence of the determinants on the demand for construction, a variance decomposition technique based on the VEC models was conducted. In previous sections, VEC models were constructed based on a pairwise combination of construction demand and the selected economic indicators. To test the predictive power of each determinant and five influencing categories, five new VEC models were structured between the construction demand and each category. Each category was represented by one or several corresponding determinants. The Johansen cointegration test results of the construction demand and each category are summarized in Table 5, which suggests that the five categories are all co-integrated with construction demand.

Variance decomposition analysis is able to describe the forecast error variance as a number of constituents which indicate the respective contribution degrees of certain variables in every prospective time. Therefore, the variable which contributes most, and those which contribute less, can be differentiated. As this study pays more attention to the contribution of determinants to the changes of demand for the construction market, only the forecast error variance for construction demand in response to its determinants is decomposed. Table 6 reports
Table 5. Johansen cointegration tests among the five categories and construction demand

\begin{tabular}{llll}
\hline Categories and indicators & Lag & M & C.Es \\
\hline Prices (CD, CPPI, NHPI, \& EXPI) & 2 & 3 & 1 \\
$\begin{array}{l}\text { Income and production } \\
\text { (CD, NI, AWE \& IPI) }\end{array}$ & 2 & 4 & 1 \\
$\begin{array}{l}\text { Demographic \& Labour force } \\
\text { (CD, POP \& LC) }\end{array}$ & 3 & 3 & 1 \\
$\begin{array}{l}\text { Consumer's expectation (CD, HHE, } \\
\text { GE, UR \& IR) }\end{array}$ & 3 & 2 & 1 \\
Other factors (CD, VOE \& BL) & 3 & 3 & 1 \\
\hline
\end{tabular}

Note: C.Es means the number of cointegration equations.

the test results of variance decomposition for construction demand in response to its determinants. It can be seen that the forecast error variance of the national income, population and unemployment rates both explain more than $23 \%$ of the forecast error variance in demand for the construction market. The construction producer price index, value of export, and household expenditure contribute, $18.12 \%, 10.37 \%$ and $7.89 \%$ respectively for the forecast error variance of construction demand. The construction producer price index, national income and average weekly earnings play key roles for affecting the growth of construction demand in the short term with approximately $20.73 \%, 10.89 \%$ and $14.63 \%$ respectively. This highlights that approximately $16 \%$ of future variations in construction demand are explained by the change of future interest rates in the third quarter. In contrast, new house price index, export price indices, average weekly earnings, industrial production index, labour costs, government expenditure and bank loans are weak in affecting future construction demand with below $5 \%$ forecast contribution.

Table 6. Variance decomposition of construction demand

\begin{tabular}{|c|c|c|c|c|c|c|c|c|c|c|c|c|c|c|}
\hline \multirow{2}{*}{$\begin{array}{l}02 \\
0 \\
.0 \\
01 \\
0\end{array}$} & \multicolumn{3}{|l|}{ Prices } & \multicolumn{3}{|c|}{$\begin{array}{l}\text { Income and } \\
\text { production }\end{array}$} & \multicolumn{2}{|c|}{$\begin{array}{l}\text { Demography } \\
\text { and labour } \\
\text { force }\end{array}$} & \multicolumn{4}{|c|}{ Consumer's expectation } & \multicolumn{2}{|c|}{ Other factors } \\
\hline & CPPI & NHPI & EXPI & NI & AWE & IPI & POP & $\mathrm{LC}$ & HHE & GE & UR & IR & VOE & $\mathrm{BL}$ \\
\hline 1 & 20.73 & 6.91 & 0.00 & 10.89 & 14.63 & 0.00 & 0.58 & 0.00 & 0.00 & 1.02 & 0.00 & 5.53 & 4.88 & 3.46 \\
\hline 2 & 21.56 & 3.93 & 0.30 & 21.24 & 10.36 & 0.05 & 5.54 & 5.04 & 0.82 & 1.34 & 1.32 & 10.91 & 4.03 & 1.03 \\
\hline 3 & 19.47 & 2.60 & 0.51 & 21.23 & 6.11 & 0.92 & 8.94 & 5.86 & 4.83 & 1.99 & 2.65 & 16.40 & 8.06 & 0.43 \\
\hline 4 & 17.95 & 1.84 & 0.55 & 22.36 & 5.06 & 1.71 & 14.59 & 5.22 & 6.01 & 2.97 & 14.68 & 13.02 & 7.78 & 0.72 \\
\hline 5 & 17.82 & 2.58 & 0.92 & 22.72 & 4.29 & 3.10 & 17.50 & 4.44 & 6.00 & 4.14 & 16.89 & 12.03 & 8.39 & 1.24 \\
\hline 6 & 18.05 & 2.49 & 1.25 & 23.31 & 3.75 & 3.66 & 20.24 & 4.46 & 6.62 & 4.45 & 18.39 & 10.85 & 8.74 & 1.58 \\
\hline 7 & 18.30 & 2.50 & 1.38 & 23.42 & 3.25 & 3.97 & 21.42 & 4.32 & 6.99 & 4.72 & 19.37 & 10.07 & 9.48 & 1.82 \\
\hline 8 & 18.26 & 2.28 & 1.46 & 23.57 & 2.91 & 3.98 & 22.41 & 3.97 & 7.03 & 4.25 & 21.52 & 9.01 & 9.86 & 1.99 \\
\hline 9 & 18.20 & 2.18 & 1.53 & 23.66 & 2.61 & 3.97 & 22.92 & 3.79 & 7.43 & 4.64 & 21.96 & 8.26 & 10.18 & 2.04 \\
\hline 10 & 18.12 & 2.17 & 1.59 & 23.81 & 2.38 & 3.94 & 23.53 & 3.68 & 7.89 & 4.87 & 23.06 & 7.64 & 10.37 & 2.10 \\
\hline
\end{tabular}




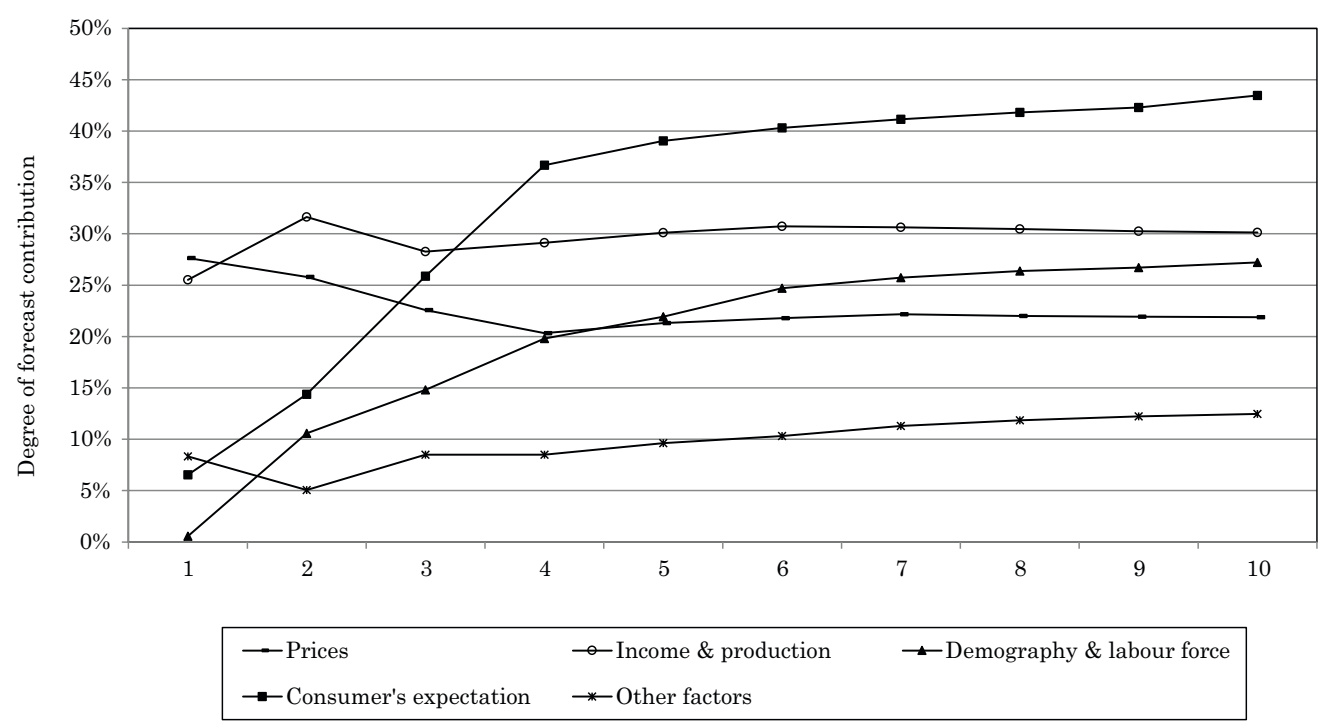

Fig. 2. Forecast contribution of the five categories to construction demand

Figure 2 displays the forecast contribution from five general categories to construction demand. The variation in construction demand can be primarily explained by future changes in consumer's expectation, income and production, demography and labour force. This figure shows construction price and other construction related prices contribute around $20 \%$ and $10 \%$ to the error variance of construction demand in Australia in the future 10 quarters. Between the future fourth quarter and the tenth quarter, the forecast error variance of the consumer's expectation explains over $40 \%$ of the forecast error variance in construction demand. In contrast, future changes in the other factors generate insignificant effects on the variation in construction demand at $10 \%$. The change of policy in the expenditure, interest rates and employment can affect the level of construction demand significantly in the future ten quarters.

After long-run and causal relationship estimations, 14 economic indicators are identified as the determinants of the demand for construction in Australia. In contrast, 11 indicators are identified as nondeterminants. The economic indicators affecting construction demand used in previous studies, and the determinants and non-determinants of construction demand identified in this study are listed in Table 7. The 17 economic indicators adopted in this study are the same or similar to those used in previous studies. However, three new influencing factors, namely, household expenditure, the export price index and labour costs are approved and both have long-run and causal relations with the demand for construction. These new determinants were found to have significant forecast contribution between $5 \%$ and $11 \%$ to the future variation of construction demand.
Table 7. Economic indicators affecting construction demand in previous studies and this study

\begin{tabular}{|c|c|c|}
\hline \multirow{2}{*}{$\begin{array}{l}\text { Determinants } \\
\text { \& non-deter- } \\
\text { minants con- } \\
\text { sidered in this } \\
\text { study }\end{array}$} & \multicolumn{2}{|c|}{$\begin{array}{l}\text { Indicators considered in previous } \\
\text { studies }\end{array}$} \\
\hline & Indicators & $\begin{array}{l}\text { Considered by } \\
\text { previous authors }\end{array}$ \\
\hline $\begin{array}{l}\text { Gross domes- } \\
\text { tic product } \\
\text { National in- } \\
\text { come }\end{array}$ & $\begin{array}{l}\text { Per capita } \\
\text { GDP, Real } \\
\text { GDP, National } \\
\text { income, income } \\
\text { per capita }\end{array}$ & $\begin{array}{l}\text { Tang et al. (1990), } \\
\text { Ofori (1990), Akin- } \\
\text { toye and Skitmore } \\
\text { (1994), Hua (1998), } \\
\text { Tse et al. (1999), } \\
\text { Lopes et al. (2004), } \\
\text { Myers (2008), Fan } \\
\text { et al. (2010) }\end{array}$ \\
\hline $\begin{array}{l}\text { International } \\
\text { investment } \\
\text { position }{ }^{\star}, \\
\text { Value of ex- } \\
\text { port, Value of } \\
\text { import }\end{array}$ & Value of export & Tang et al. (1990) \\
\hline
\end{tabular}

Government expenditure, Household expenditure $\boldsymbol{}$, Value of retail trade $^{\star}$

Government revenue and Tang et al. (1990) expenditure

Householder and corporate savings *

Housing stock or number of planning or construction approvals *

Industrial production index, Total manufacturing production index ${ }^{\star}$ Industrial output or investment

Tang et al. (1990)

Ofori (1990), Hua (1998, 2000), Ball et al. (1998), Tse et al. (1999)

Tang et al. (1990), Ball et al. (1998), Song and Liu (2006)

Land supply * Fan et al. (2010)

(Continued) 


\begin{tabular}{|c|c|c|}
\hline \multirow{2}{*}{$\begin{array}{l}\text { Determinants } \\
\text { \& non-deter- } \\
\text { minants con- } \\
\text { sidered in this } \\
\text { study }\end{array}$} & \multicolumn{2}{|c|}{$\begin{array}{l}\text { Indicators considered in previous } \\
\text { studies }\end{array}$} \\
\hline & Indicators & $\begin{array}{l}\text { Considered by } \\
\text { previous authors }\end{array}$ \\
\hline \multicolumn{3}{|l|}{ (Continued) } \\
\hline $\begin{array}{l}\text { Construc- } \\
\text { tion producer } \\
\text { price index }\end{array}$ & $\begin{array}{l}\text { Construc- } \\
\text { tion cost or } \\
\text { construction } \\
\text { tender price or } \\
\text { building mate- } \\
\text { rial price index }\end{array}$ & $\begin{array}{l}\text { Tang et al. }(1990), \\
\text { Akintoye and Skit- } \\
\text { more (1994), Hua } \\
(1998), \text { Myers (2008), } \\
\text { Fan et al. }(2010)\end{array}$ \\
\hline $\begin{array}{l}\text { New house } \\
\text { price index, } \\
\text { Established } \\
\text { house price in- } \\
\text { dex }^{\star}, \text { Import } \\
\text { price index } \\
\text { Export price } \\
\text { index }\end{array}$ & $\begin{array}{l}\text { Property price } \\
\text { and relative } \\
\text { price index }\end{array}$ & $\begin{array}{l}\text { Ofori (1990), Hua } \\
\text { (2000), Tse } \text { et al. } \\
\text { (1999), Myers (2008), } \\
\text { Fan et al. }(2010)\end{array}$ \\
\hline $\begin{array}{l}\text { Unemploy- } \\
\text { ment rate, } \\
\text { Employed } \\
\text { person in } \\
\text { construction } \\
\text { industry }\end{array}$ & $\begin{array}{l}\text { Labour force, } \\
\text { Unemploy- } \\
\text { ment rate, } \\
\text { Labour pro- } \\
\text { ductivity }\end{array}$ & $\begin{array}{l}\text { Akintoye and Skit- } \\
\text { more }(1994), \text { Hua } \\
(1998,2000), \text { Ball } \\
\text { et al. }(1998), \text { Wong } \\
\text { et al. }(2007), \text { Fan } \\
\text { et al. }(2010)\end{array}$ \\
\hline $\begin{array}{l}\text { Size of popu- } \\
\text { lation }\end{array}$ & $\begin{array}{l}\text { Size of popula- } \\
\text { tion or popula- } \\
\text { tion growth }\end{array}$ & $\begin{array}{l}\text { Tang et al. }(1990) \text {, } \\
\text { Hua (2000), Myers } \\
(2008), \text { Fan } \text { et al. } \\
(2010)\end{array}$ \\
\hline $\begin{array}{l}\text { Construc- } \\
\text { tion company } \\
\text { profit }{ }^{\star}\end{array}$ & $\begin{array}{l}\text { Profitability } \\
\text { (manufactur- } \\
\text { ing price to } \\
\text { cost ratio) }\end{array}$ & $\begin{array}{l}\text { Akintoye and Skit- } \\
\text { more (1994) }\end{array}$ \\
\hline $\begin{array}{l}\text { Average week- } \\
\text { ly earnings, } \\
\text { Labour cost }\end{array}$ & $\begin{array}{l}\text { Income or real } \\
\text { wage }\end{array}$ & $\begin{array}{l}\text { Ofori (1990), Wong } \\
\text { et al. (2007), Myers } \\
\text { (2008), Fan et al. } \\
(2010)\end{array}$ \\
\hline $\begin{array}{l}\text { Bank loans, } \\
\text { Value of hous- } \\
\text { ing finance } \\
\text { commitment }^{\star}\end{array}$ & $\begin{array}{l}\text { Housing loans, } \\
\text { Central provi- } \\
\text { dent fund and } \\
\text { others }\end{array}$ & Hua $(1998,2000)$ \\
\hline \multirow[t]{2}{*}{$\begin{array}{l}\text { Interest rate, } \\
\text { Australia } \\
\text { stock market } \\
\text { index }{ }^{\star}\end{array}$} & $\begin{array}{l}\text { Interest rate or } \\
\text { prime lending } \\
\text { rate }\end{array}$ & $\begin{array}{l}\text { Tang et al. (1990), } \\
\text { Ofori (1990), Akin- } \\
\text { toye and Skitmore } \\
(1994) \text {, Tse } \text { et al. } \\
\text { (1999), Myers (2008), } \\
\text { Fan et al. }(2010)\end{array}$ \\
\hline & $\begin{array}{l}\text { Number of } \\
\text { tourist * }\end{array}$ & Tang et al. (1990) \\
\hline
\end{tabular}

$\star$ denotes the indicators identified as non-determinants of construction demand.

$\boldsymbol{\Delta}$ denotes the determinants not considered in previous studies.

* denotes the indicators considered in previous studies but unused in this study.

Meanwhile other previously untested economic indicators, the value of import, the Australia stock market index, the international investment position, the import price index and the value of retail trade, are identified as non-determinants of construction demand. The householder and corporate savings, housing stock, the land supply and the number of tourists are not involved in this study due to the lack of statistical data available for these indicators. However, householder and corporate savings, housing stock, land supply, number of tourists, GDP and housing loans played insignificant roles for modelling the demand for construction in the studies of Tang et al. (1990); Hua (1998) and Fan et al. (2010). It was also found that not all types of property prices have links with construction demand. In Australia changes in new house prices can affect the level of demand but the established house prices cannot. Therefore, the irrationality of a determinant-identifying approach can be verified according to the comparison results.

\section{CONCLUSIONS}

This study has delivered an innovative approach for identifying and evaluating the economic determinants of demand for the construction market. The economic indicators adopted in this study are classified in five categories based on demand theory. The effects of economic indicators and categories on the growth of demand in the construction market are estimated in this study. A series of econometric techniques, Johansen cointegration, Granger causality and forecast error-variance decomposition estimations have been employed to explore the long-run and causal relations and to evaluate the forecast contributions of economic indicators on the demand for construction. The conclusions can be stated as follows:

In this study, 14 economic indicators have been identified as the determinants of demand for the Australian construction market based on long-run and causal relationship estimations. It is important for construction contractors, tenders and developers to observe the fluctuation of construction price, national income, size of population, unemployment rates, the value of export, interest rates and the household expenditure in order to predict the future demand for the construction market as these determinants are the most important factors able to explain the level of demand for construction. Changes in categories of consumer's expectation, demography and labour force, income and production play key roles in explaining the future variation of demand for construction in the future ten quarters. In contrast, change in the category of other factors (value of export and bank loans) has the least influence in affecting the future construction demand during the study period. 
Compared with previous studies in the field of construction demand and economic indicators, three indicators, namely household expenditure, the export price index and labour costs, were found to be new determinants in this study. Strong links were proven between these determinants and the level of demand in the construction market. Furthermore, policies that enhance employment and encourage the export of goods and services can help to raise the demand in the Australian construction market significantly. It was also revealed that while the fluctuation of new house prices can affect the level of demand in the construction market, established house prices cannot. This study focuses on identifying determinants of construction demand at the overall level. The construction market may be classified by types and sectors, such as residential, commercial, office, industrial, private and public markets. Identifying the determinants of demand for different construction types and sectors should be further investigated in the future.

\section{REFERENCES}

ABS. 2011. Australian economic indicators, by ABS, July Quarter ed. edn, Australia Bureau of Statistics.

Akintoye, A.; Skitmore, M. 1994. Models of UK private sector quarterly construction demand, Construction Management and Economics 12(1): 3-13. http://dx.doi.org/10.1080/01446199400000002

Akintoye, A.; Skitmore, M. 1991. The supply of construction services: an econometric analysis of UK data, in Malcom, Horner and Marko, Zaja (Eds.), in Proceedings 4th Yugoslav Symposium Construction Project Modeling and Productivity, University of Zagreb, Yugoslavia, 109-115.

Ball, M.; Lizieri, C.; MacGregor, B. D. 1998. The economics of commercial property markets. London: Routledge.

Fan, R. Y. C.; Ng, S. T.; Wong, J. M. W. 2010. Reliability of the Box-Jenkins model for forecasting construction demand covering times of economic austerity, Construction Management and Economics 28(3): 241254. http://dx.doi.org/10.1080/01446190903369899

Gyourko, J.; Saiz, A. 2006. Construction costs and the supply of housing structure, Journal of Regional Science 46(4): 661-680. http://dx.doi.org/10.1111/j.14679787.2006.00472.x

Hua, G. B. 1998. Forecasting residential construction demand in Singapore: a comparative study of the accuracy of time series, regression and artificial neural network techniques, Engineering, Construction and Architectural Management 5(3): 261-275. http://dx.doi.org/10.1111/j.1365-232X.1998.eca_48.x

Hua, G. B. 2000. Evaluating the performance of combining neural networks and genetic algorithms to forecast construction demand: the case of the Singapore residential sector, Construction Management and Economics 18(2): 209-217. http://dx.doi. org/10.1080/014461900370834

Hua, G. B. 2005. The dynamic effects of the Asian financial crisis on construction demand and tender price levels in Singapore, Building and Environment 40(2): 267-276. http://dx.doi.org/10.1016/j. buildenv.2004.07.012

Hui, E. C. M.; Yue, S. 2006. Housing price bubbles in Hong Kong, Beijing and Shanghai: a comparative study, Journal of Real Estate Finance and Economics 33(4): 299-327. http://dx.doi.org/10.1007/s11146006-0335-2

Jiang, H.; Liu, C. 2011. Forecasting construction demand: a vector error correction model with dummy variables, Construction Management and Economics 22(9): 969-979. http://dx.doi.org/10.1080/01446193.2 011.611522

Liu, C.; Ma, L.; Luo, Z.; Picken, D. 2009. An interdependence analysis of Australian house prices using variance decomposition, International Journal of Housing Markets and Analysis 2(3): 218-232. http://dx.doi.org/10.1108/17538270910977527

Lopes, J.; Nunes, A.; Balsa, C. 2011. The long-run relationship between the construction sector and the national economy in Cape Verde, International Journal of Strategic Property Management 15(1): 48-59. http://dx.doi.org/10.3846/1648715X.2011.565909

Luo, Z.; Liu, C.; Picken, D. 2007. Housing price diffusion pattern of Australia's state capital cities, International Journal of Strategic Property Management 11(4): 227-242.

Myers, D. 2008. Construction economics. London: Taylor \& Francis.

Ng, S.; Fan, R. Y. C.; Wong, J. M. W. 2011. An econometric model for forecasting private construction investment in Hong Kong, Construction Management and Economics 29(5): 519-534. http://dx.doi.org/10.1080/ 01446193.2011 .570356

Ofori, G. 1990. The construction industry: aspects of its economics and management. Singapore: Singapore University Press.

Song, Y.; Liu, C. 2006. The Australian construction linkages in the 1990s, Architectural Science Review 49(4): 408-417. http://dx.doi.org/10.3763/asre.2006.4953

Tang, J. C. S.; Karasudhi, P.; Tachopiyagoon, P. 1990. Thai construction industry: demand and projection, Construction Management and Economics 8(3): 249257. http://dx.doi.org/10.1080/01446199000000022

Tse, R. Y. C.; Ho, C. W.; Ganesan, S. 1999. Matching housing supply and demand: an empirical study of Hong Kong's market, Construction Management and Economics 17(5): 625-633. http://dx.doi. org/10.1080/014461999371231

Wong, J. M. W.; Chan, A. P. C.; Chiang, Y. H. 2007. Forecasting construction manpower demand: a vector error correction model, Building and Environment 42(8): 3030-3041. http://dx.doi.org/10.1016/j. buildenv.2006.07.024 